\title{
Life histories and abundance patterns of colonial corals on Jamaican reefs
}

\author{
Katharine W. Rylaarsdam* \\ Department of Earth and Planetary Sciences, The Johns Hopkins University, Baltimore, Maryland 21218 , USA
}

\begin{abstract}
Large-scale patchiness within the cervicornis zone at Discovery Bay, Jamaica, before the recent hurricane was due chiefly to variations in cover of Acropora cervicornis. Montastrea annularis and Agaricia agaricites, the 2 other important species in the zone, varied less among 3 sites surveyed, though $M$. annularis had slightly greater cover on the exposed east forereef. Relative species abundances of corals $<5 \mathrm{~cm}$ in diameter were very different from those in the total faunas. In all areas, $A$. agaricites predominated. A. cervicornis and $M$. annularis were rare. To examine processes producing the abundance patterns, life history observations were made on natural massive substrata surveyed in June 1977 and September 1978, and experimental substrata set out in April 1977 and examined from December 1977 to March 1978 and from October 1978 to January 1979. Agariciids were even more important as recruits than in the small-coral abundance data. Growth of small corals was variable, apparently somewhat greater in the branching $A$. cervicornis than in other species. Mortality on experimental substrata was $>90 \%$, as compared with $<60 \%$ for natural substrata. The difference probably reflected the smaller size of corals on experimental substrata: size differences had a significant effect on mortality on natural substrata. Five-day laboratory experiments with the omnivorous echinoid Diadema antillarum showed that its grazing activities could cause strongly size-dependent early mortality. Extrapolation suggested that a coral remaining $<3 \mathrm{~mm}$ in diameter for 2 to 3 mo would have only a $20 \%$ chance of surviving longer. With minor specific differences in early growth, the small-coral abundance patterns might thus develop from recruitment patterns. In feeding experiments, the common predators Hermodice carunculata and Coralliophila abbreviata both showed a strong preference for $A$. cervicornis. Coralliophila also ate $M$. annularis, but $A$. agaricites was untouched. Apparently the activities of these predators alone would simply increase the relative abundance of the predominant small coral. Known routine processes in this system are insufficient to account for the abundance patterns of corals in the zone. These results emphasize the need to consider long-term processes and rare events in accounting for the abundance of long-lived colonial organisms.
\end{abstract}

\section{INTRODUCTION}

On coral reefs, as in forests, physical structure is provided by the predominant organisms, which are characterized by long life spans and indeterminate growth. As in any other system, the dynamics of these communities reflect the dynamics of their component populations, but the population biology of colonial corals is poorly known and poorly understood theoretically. In this study, 'reproduction' refers to sexual reproduction, 'recruitment' to the settlement of larvae, and 'individuals' are genetically distinct (cf. Harper, 1977; White, 1979). Because of the long life spans of many scleractinian corals and the phenomenon of col-

\footnotetext{
- Present address: 3811 Canterbury Road, \#505, Baltimore, Maryland 21218, USA
}

ony fission resulting from extensive polyp mortality (Lewis, 1974; Hughes and Jackson, 1980), a colony is not necessarily an individual, and its size is poorly correlated with age. Population structure cannot be fully described by counts of colonies, and the least ambiguous measures of species' abundances are provided by cover data.

Abundance patterns of corals show marked zonation with depth, as described by Goreau (1959), Goreau and Goreau (1973), and Kinzie (1973) for the reefs of Jamaica's north coast. One of the most striking of the zones is dominated by the branching Acropora cervicornis (Lamarck) and extends from $-10 \mathrm{~m}$ to $-20 \mathrm{~m}$ (Kinzie, 1973). Yet observations made at Discovery Bay in 1976 reveal large-scale patchiness within the cervicornis zone (Rylaarsdam, 1980). This could be due to past history, ongoing processes, or some combination 
of the two. If ongoing processes are important, the differences in coral faunas among areas could be due either to differential recruitment by habitat selection or restricted dispersal or to differential mortality or growth among species.

This study examines some of the processes affecting coral abundance patterns in the cervicornis zone. It focuses on the early population dynamics of common Caribbean reef corals and a few major causes of mortality which can operate throughout the corals' lives. Competitive interactions have already been well studied (Lang, 1973; Ohlhorst, 1980). Physical factors are not considered: within-habitat variation in light and water movement probably exceeds variation among the areas studied, and the common coral species do not differ in their ability to deal with intermittent sedimentation in the field (Rylaarsdam, 1980 and in prep.). The questions it addresses are: (1) What were the relative abundances of coral species in 3 different areas in the zone? (2) What were the relative abundances of small corals (younger on average) in these areas? Did they suggest that differential recruitment could be largely responsible for the composition of the total faunas? (3) What were the rates of recruitment, growth, and mortality of small corals on (a) natural substrata and (b) experimental substrata in the study areas? (4) What were the relative susceptibilities of selected common coral species to specific sources of mortality, viz. grazing by the echinoid Diadema antillarum Philippi, and predation by the polychaete Hermodice carunculata (Pallas) and the gastropod Coralliophila abbreviata Lamarck?

The results show that the patterns of recruitment are extremely different from those of cover in the cervicornis zone: subsequent growth, injury, and repair processes must play a major role in producing the abundance patterns of corals. High turnover of both polyps and small colonies on a short time scale is tied to slow

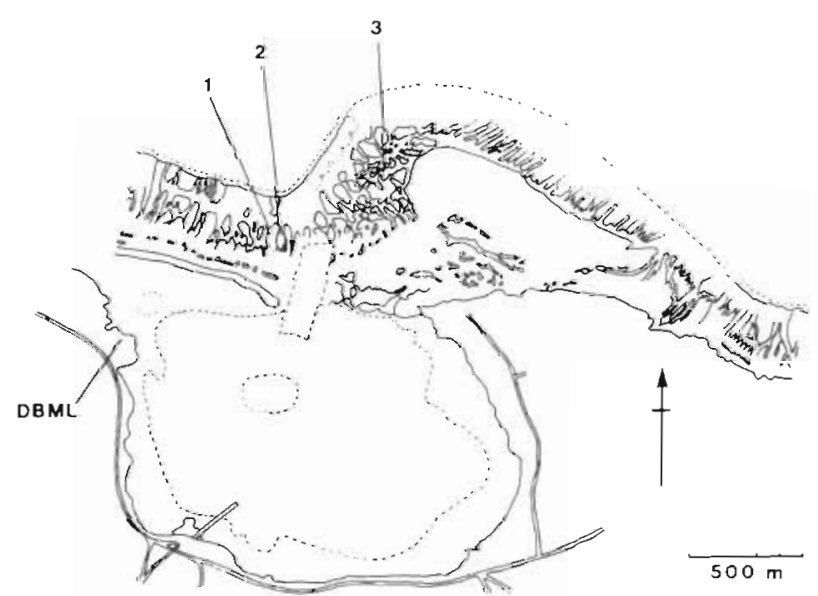

Fig. 1. Discovery Bay. DBML: laboratory; 1: Upper Buoy Reef, $-11 \mathrm{~m}_{\mathrm{i}}$ 2: Sand channel, $-14 \mathrm{~m}$; 3: East forereef, $-15 \mathrm{~m}$ developments and rare events over much longer periods, and the population biology of the organisms involved at both levels of activity is necessarily complex.

\section{STUDY AREAS}

The research was done between 1976 and 1979 at the Discovery Bay Marine Laboratory of the University of the West Indies on the north coast of Jamaica (Fig. 1). The forereef there is divided by a ship channel through the crest. To the west it has a marked slope, and below the crest divides into tongues of actively growing reef separated by widening sand channels, most of which merge at about - $20 \mathrm{~m}$ where the slope steepens (Kinzie, 1973). Two study areas were established.

The first area (1 in Fig. 1) was on Upper Buoy Reef at $-11 \mathrm{~m}$. The reef surface was complex, consisting of the fused, eroded, and encrusted skeletons of massive and branching corals covered in many places by a dense mesh of Acropora cervicornis branches, the lower parts of which were dead and in various stages of being reduced to rubble. Fleshy algae were common only in damselfish territories; elsewhere the dead coral substratum was heavily grazed, especially by echinoids, of which the most common was the spiny black Diadema antillarum. (North coast reefs have been heavily fished in recent decades, and piscine grazers were relatively unimportant.) Large massive corals occurred at intervals among the branches, as did some sponges and gorgonians.

The second area (2 in Fig. 1) was in the sand channel east of Upper Buoy Reef at a depth of - $14 \mathrm{~m}$; the larger sand channels on the west forereef are commonly about $3 \mathrm{~m}$ deeper than the adjacent reefs (see Kinzie, 1973, for a picture of a boundary). Live coral and hard substratum alike were provided chiefly by isolated mounds ( $<1 \mathrm{~m}$ across) of massive corals which had been partially killed, bored, and grazed. Sponges and algae occurred sporadically, primarily in sheltered crevices

The east forereef rests on a broad, gently sloping platform. Though relatively more exposed to the prevailing wind and currents, it has fewer directional features than the west forereef (except on its far eastern edge, beyond Discovery Bay). Over most of the platform, patches of rock and actively growing coral alternate with patches of sand and loose rubble at almost the same depth. The sand patches range in size from narrow rivulets and small pockets to large open areas (ca. 10 to $30 \mathrm{~m}$ across): rock patches span a similar range. The study area there, at $-15 \mathrm{~m}$, included both reef surface with a little sand and part of a large sand area with a little coral; by extension of Kinzie's (1973) west forereef zonation, it was in the lower cervicornis 
zone. The fauna included a variety of large sponges and gorgonians as well as many massive corals; Acropora cervicornis was moderately important. Available hard substratum was about as common as live coral.

\section{COMMON CORALS}

Three species were common in the cervicornis zone. Brief descriptions are provided to emphasize important morphological differences among them.

Acropora cervicornis has tapered, irregular branches roughened by narrow exsert corallites. Colonies can range to over $1 \mathrm{~m}$ in height but more often break apart before reaching that size. A new recruit forms a small patch on the substratum with projecting corallites, one of which gives rise to a single branch. Corallites on the branch point at an angle away from the substratum; their orientation is useful in distinguishing recruited colonies from reattached fragments. Since any corallite can become the axis for a new branch, at a characteristically large acute angle, subsequent growth is extremely plastic.

Agaricia agaricites (Linnaeus) may be encrusting, plating, or moundlike, often very irregular, with the mouths of polyps sunk in discontinuous valleys bounded by sharp ridges. It can attain a diameter of $1 \mathrm{~m}$, but in these areas seldom does. Recruits form flat, almost smooth discs about $1 \mathrm{~mm}$ across, but after these expand and 2 or 3 mouths have been added, the ridges begin forming between them and the colony grows higher above the substratum.

Montastrea annularis (Ellis \& Solander) may be hemispherical, moundlike and irregular, knobby, columnar, or plating (see Barnes, 1973, for excellent pictures). Colonies occasionally reach diameters of several meters. The surface of a colony is relatively smooth, as the differentiation of polyps is not reflected in high skeletal relief. New recruits are similar in size to those of Agaricia agaricites, or a little larger, and stand slightly higher above the substratum.

\section{METHODS AND RESULTS}

Since diverse types of data were used to answer the questions in the introduction, details of the methods are described immediately prior to the results for each.

\section{Coral abundances - percent cover}

Percent cover was determined from chain-link transects (Porter, 1972) using a $3.75 \mathrm{~m}$ chain with $2 \mathrm{~cm}$ links. One end of the chain was dropped haphazardly (by chance) in a study area, and the chain extended approximately parallel to the reef crest. It was roughly horizontal but drooped slightly where the relief of underlying structures changed abruptly. The coral species or other objects (e.g. sponge, sand, encrusted rock) lying under successive links were recorded. This procedure was repeated several times in each area (minimum 9) until a graph of species number vs. links of live coral transected had reached a plateau (cf. Pielou, 1977) and the relative abundance of the most common species varied by no more than 2 to $3 \%$ with additional data. These criteria gave limited consideration to the effects of patchiness; but the mean abundances of all species are in line with the impressions of an observer swimming over the areas, and the confidence intervals are good for the common species. All areas were surveyed in 1976.

The coral faunas of the 3 areas differed markedly, despite the number of species they had in common (Table 1, Fig. $2 ; \chi^{2}$ on the 3 locally dominant species and lumped 'others' is $364.484, \mathrm{p} \ll .001$ ). The fauna at
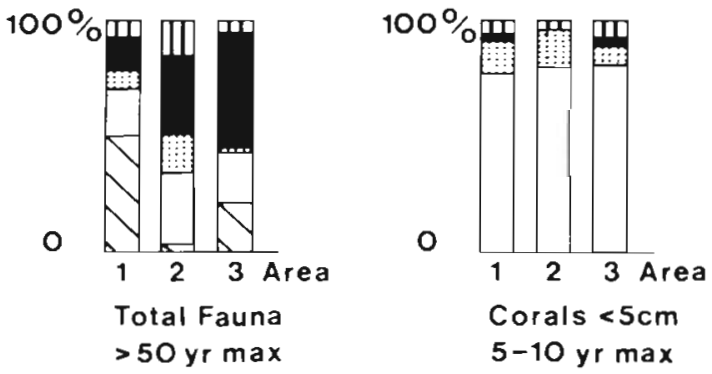

Natural Substrata
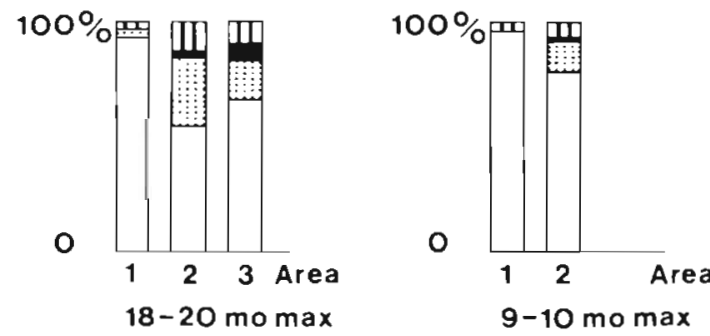

Experimental Substrata

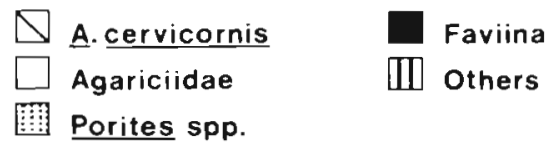

Fig. 2. Relative abundances of corals. Graphs represent relative abundances in faunas with different age ranges; upper limit is indicated under each. Total fauna described by cover data, smaller size classes by counts. Study areas numbered as in Fig. 1. Family Agariciidae includes Agaricia spp. and $L$. cucullata; Suborder Faviina includes Montastrea spp. and $C$. natans, and less common species which could not be identified at small sizes 
Table 1. Relative abundances of corals in 3 areas in the cervicornis zone in 1976. Percentages based on transect (cover) data, with $95 \%$ confidence intervals based on normal approximations (appropriate for common species). Each transect $3.75 \mathrm{~m}$ (186 chain links) in length

\begin{tabular}{|c|c|c|c|}
\hline \multirow[t]{2}{*}{ Species } & \multicolumn{2}{|c|}{ West Forereef } & \multirow{2}{*}{$\begin{array}{l}\text { East Foreree } \\
\qquad(-15 \mathrm{~m})\end{array}$} \\
\hline & $\begin{array}{c}\text { Upper Buoy Reef } \\
(-11 \mathrm{~m})\end{array}$ & $\begin{array}{l}\text { Sand channel } \\
\quad(-14 \mathrm{~m})\end{array}$ & \\
\hline Acropora cervicornis & $49 \pm 12$ & $1 \pm 2$ & $21 \pm 26$ \\
\hline Agaricia agaricites & $17 \pm 7$ & $32 \pm 11$ & $20 \pm 24$ \\
\hline Siderastrea siderea & $4 \pm 7$ & $3 \pm 3$ & $6 \pm 1$ \\
\hline Porites astreoides & $2 \pm 3$ & $5 \pm 5$ & $2 \pm 4$ \\
\hline Porites furcata & $6 \pm 4$ & $12 \pm 11$ & $0 \pm 0$ \\
\hline Colpophyllia natans & $6 \pm 9$ & $6 \pm 9$ & \\
\hline Montastrea annularis & $7 \pm 7$ & $21 \pm 11$ & $32 \pm 24$ \\
\hline Montastrea cavernosa & & $6 \pm 6$ & $14 \pm 12$ \\
\hline Millepora spp. & $1 \pm 2$ & $7 \pm 8$ & $1 \pm 1$ \\
\hline Others (11 spp.) & $9 \pm 5$ & $7 \pm 7$ & $4 \pm 4$ \\
\hline Total coral cover & $33 \pm 8$ & $19 \pm 6$ & $26 \pm 12$ \\
\hline Number of transects & 10 & 11 & 9 \\
\hline
\end{tabular}

Upper Buoy Reef was dominated by Acropora cervicornis. That in the sand channel was characterized by Agaricia agaricites and Montastrea annularis, with patchily abundant Porites furcata (Lamarck) and almost no A. cervicornis. That on the east forereef included several species of almost equal importance: $M$. annularis, $A$. cervicornis, A. agaricites, and quite a lot of $M$. cavernosa (Linnaeus). The differences among faunas were influenced most strongly by $A$. cervicornis, which had higher cover at Upper Buoy Reef than anywhere else, and to a lesser degree by $M$. annularis, which was apparently slightly more abundant on the east forereef. A. agaricites had roughly equal cover in all areas (cf. total coral cover and the relative abundances of individual species in Table 1).

\section{Small-coral abundances}

Since smaller colonies must be younger on average than large, relative abundances of small corals should indicate whether a general abundance pattern is likely to have been established by recruitment or early mortality rather than by processes acting later. Abundances of small corals were estimated from counts of colonies which were $<5 \mathrm{~cm}$ in greatest diameter and appeared to be original rather than remnants of larger colonies. The latter criterion was not met if a colony had a thin, poorly defined edge, particularly if corallites along the colony's edge appeared almost continuous with eroded corallites on the adjacent substratum. I selected discrete patches of substratum and recorded the species and size of every 'original' small coral found in a close scrutiny of the surface. The substrata were of encrusted or recently dead coral rock without abundant fleshy algae or animals which could have prevented coral recruitment; except for that restriction, selection was haphazard. Their topographic complexity prohibited precise estimates of their surface areas, but these were probably 2 to $.3 \mathrm{~m}^{2}$, varying according to natural topographic discontinuities and limited by diving time. Coral sizes were recorded as greatest diameters of $<.5,5,1,2,3,4$, or $5 \mathrm{~cm}$, using a centimeter rule; the margin of error was about $.5 \mathrm{~cm}$ for the larger sizes and $1 \mathrm{~mm}$ to $2 \mathrm{~mm}$ for the 2 smallest. The criteria for determining the number of samples (usually 4 area $^{-1}$ ) were the same as for the transect data.

The small-coral faunas of the 3 areas were more uniform than the total abundance patterns (Table 2 , Fig. $2 ; \chi^{2}$ on Agaricia agaricites, Leptoseris cucullata [Ellis \& Solander], lumped poritids, and lumped 'others' is $12.854, \mathrm{p}<.05$ by a small margin, due mostly to differences in the last, broad category). All consisted predominantly of $A$. agaricites, with $L$. cucullata and poritids. In no area did they resemble the composition of the total coral fauna. Most notable was the extreme rarity of small colonies of Acropora cervicornis and Montastrea annularis, the species which contributed most to the differences among the faunas of the 3 areas.

\section{Life history observations of small corals}

Natural substrata - corals up to a few years in age

Four substrata were censused in each of the areas in June 1977, 2 near each of 2 marker buoys. At least 2 sizable pieces of the substratum disappeared (an unanticipated but apparently common phenomenon), 
Table 2. Relative abundances of small $(<5 \mathrm{~cm})$ corals in 3 areas in the cervicornis zone. Percentages based on counts of clearly intact individuals, with $95 \%$ confidence intervals based on normal approximation

\begin{tabular}{|c|c|c|c|c|c|c|c|c|}
\hline \multirow[t]{3}{*}{ Species } & \multicolumn{6}{|c|}{ West Forereef } & \multirow{2}{*}{\multicolumn{2}{|c|}{$\begin{array}{c}\text { East Forereef } \\
\quad(-15 \mathrm{~m})\end{array}$}} \\
\hline & \multicolumn{3}{|c|}{ Upper Bouy Reef $(-11 \mathrm{~m})$} & \multicolumn{3}{|c|}{ Sand channel $(-14 \mathrm{~m})$} & & \\
\hline & 1976 & 1977 & 1978 & 1976 & 1977 & 1978 & 1976 & 1977 \\
\hline Stephanocoenia michelini & $3 \pm 5$ & & $0 \pm 1$ & $3 \pm 4$ & $2 \pm 5$ & $2 \pm 4$ & $7 \pm 6$ & $3 \pm 16$ \\
\hline Acropora cervicornis & & $1 \pm 1$ & $1 \pm 2$ & & & $0 \pm 1$ & & \\
\hline Agaricia agaricites & $59 \pm 23$ & $56 \pm 22$ & $54 \pm 23$ & $58 \pm 10$ & $70 \pm 22$ & $65 \pm 19$ & $63 \pm 17$ & $62 \pm 38$ \\
\hline Leptoseris cucullata & $16 \pm 9$ & $13 \pm 11$ & $18 \pm 19$ & $18 \pm 8$ & $13 \pm 22$ & $18 \pm 19$ & $13 \pm 15$ & $14 \pm 15$ \\
\hline unidentified agariciids & $1 \pm 3$ & $12 \pm 14$ & $6 \pm 6$ & $3 \pm 5$ & $11 \pm 22$ & $10 \pm 6$ & $4 \pm 9$ & $8 \pm 21$ \\
\hline Porites astreoides & $8 \pm 5$ & $6 \pm 8$ & $5 \pm 4$ & $13 \pm 9$ & $2 \pm 6$ & $1 \pm 2$ & $5 \pm 6$ & $7 \pm 8$ \\
\hline Porites furcata & $5 \pm 10$ & $10 \pm 8$ & $9 \pm 10$ & $2 \pm 3$ & $3 \pm 8$ & $1 \pm 2$ & $1 \pm 2$ & $3 \pm 7$ \\
\hline Porites spp. & $2 \pm 6$ & & $0 \pm 1$ & $1 \pm 3$ & & & $2 \pm 6$ & \\
\hline Montastrea annularis & $1 \pm 2$ & & & & & & & \\
\hline Millepora spp. & $2 \pm 3$ & $2 \pm 6$ & $3 \pm 4$ & $0 \pm 1$ & & $1 \pm 2$ & & \\
\hline Others ( 7 spp. \& unidentified) & $1 \pm 2$ & & $4 \pm 5$ & $5 \pm 9$ & $1 \pm 2$ & $2 \pm 3$ & $6 \pm 4$ & $3 \pm 13$ \\
\hline Number of substrata sampled & 4 & 4 & 4 & 4 & 4 & 5 & 4 & 3 \\
\hline Total number of corals & 233 & 108 & 274 & 183 & 76 & 207 & 190 & 113 \\
\hline
\end{tabular}

but in September 1978 I relocated 2 substrata on Upper Buoy Reef and 3 in the sand channel. The east forereef markers were lost, and those substrata could not be reexamined.

The procedure was similar to that used in estimating abundances of small corals: the only addition was a record of the colonies' positions. I used a system of 3dimensional coordinates extending roughly $\pm 20 \mathrm{~cm}$ in each dimension, depending on the shape of the substratum. Definition of life history parameters was straightforward. Colonies present only at the second census were called recruits; those missing at the second census were presumed dead; growth was measured as change in maximum diameter, and was sometimes negative.

\section{Experimental substrata - corals $<2$ yr in age}

The experimental substrata were branches of Acropora cervicornis killed and cleaned in fresh water and trimmed so that they approximated cylinders $40 \mathrm{~cm}$ in length. There were 80 in each study area, tied to frames of PVC pipe in various replicated cage treatments (Rylaarsdam, 1980). Coral densities were so low that treatment effects were not significant, however. The branches were in fixed, approximately horizontal positions with $25 \mathrm{~cm}$ between their attachment points. They were set out in April of 1977, in an area of about $100 \mathrm{~m}^{2}$ at each site, and censused from December 1977 to March 1978 and from October 1978 to January 1979. Severe storms during the first winter delayed the work and damaged the east forereef treatments so badly that maintenance was abandoned; those substrata were examined only at the end of the study.
At the first census, 10 substrata in each area were left in place as transport controls while the others were taken to the wet laboratory, examined under a dissecting microscope, and returned to the reef; at the second, all were collected. Only the length of branch between attachment points was examined; since branch circumferences were about $6 \mathrm{~cm}$, this approximated a surface area of $150 \mathrm{~cm}^{2}$ substratum ${ }^{-1}$. Thus the corals observed at each site occupied a total area of about $1.05 \mathrm{~m}^{2}(70$ branches) at the first census, $1.2 \mathrm{~m}^{2}$ (80 branches) at the second.

For each coral I recorded position (quadrant of branch and millimeters from one attachment point), 2 orthogonal diameters (to the nearest $\mathrm{mm}$ ), condition, and probable species. Life history parameters were defined as for corals on natural substrata, but I added an alternative measure of recruitment less biased by early mortality than the 10 -monthly net rates based on total numbers of new corals at each census. Since corals begin growing soon after attachment, I assumed that any coral of $1 \mathrm{~mm}$ diameter had recruited in the preceding month, while any larger was older. This assumption was undoubtedly more realistic for some species than for others, but the monthly net recruitment rates obtained in this manner provide a useful contrast to the more conventional measure.

\section{Recruitment}

Both net monthly recruitment rates and new corals found after 9 to 10 mo on experimental substrata were lower for the sand channel than for either other area (Table 3). The monthly rates, though derived from several different months, are quite consistent with the 
Table 3 . Recruitment on experimental substrata in 3 areas. Based on (a) total new colonies at time of census $\leq 10$ mo old, except East forereef $\leq 20$ mo old; (b) in parentheses, colonies $\leq 1 \mathrm{~mm}$ in diameter, assumed $\leq 1$ mo old

\begin{tabular}{|c|c|c|c|c|c|}
\hline \multirow{3}{*}{ Corals } & \multicolumn{4}{|c|}{ West Forereef } & \multirow{3}{*}{$\begin{array}{l}\text { East Forereef } \\
\text { 2nd (only) census } \\
\text { Dec'78-Jan } 79\end{array}$} \\
\hline & \multicolumn{2}{|c|}{ Upper Buoy Reef } & \multicolumn{2}{|c|}{ Sand channel } & \\
\hline & $\begin{array}{l}\text { 1st census } \\
\text { Dec } 77\end{array}$ & $\begin{array}{c}2 \text { nd census } \\
\text { Oct ' } 78\end{array}$ & $\begin{array}{l}\text { 1st census } \\
\text { Jan-Feb '78 }\end{array}$ & $\begin{array}{l}\text { 2nd census } \\
\text { Nov } 78\end{array}$ & \\
\hline Agariciids & $284(130)$ & $311(100)$ & $81(51)$ & $95(51)$ & $197 \quad(66)$ \\
\hline porites astreoides & & 7 & 12 (1) & $41 \quad(4)$ & $32 \quad(1)$ \\
\hline Porites spp. & & 2 & 2 & $2(1)$ & $17 \quad(7)$ \\
\hline Faviina, finely dentate & & $3 \quad(1)$ & 1 & $3(1)$ & 12 \\
\hline Faviina, strongly dentate & & & & & $10 \quad(2)$ \\
\hline Others & $14 \quad(5)$ & $12 \quad(3)$ & $8 \quad(4)$ & $24(15)$ & $28 \quad(21)$ \\
\hline Total new & $298(135)$ & $335(104)$ & $104(56)$ & $165(72)$ & $296(100)$ \\
\hline Total present & 298 & 349 & 104 & 174 & 296 \\
\hline
\end{tabular}

other data. They imply a much higher settlement rate, however.

Agariciid recruitment far exceeded that of any other group, ranging from $66 \%$ of the total on the east forereef to $96 \%$ on Upper Buoy Reef at the first census. Poritids ran a distant second, and seemed less common on Upper Buoy Reef. Unidentified Faviina, perhaps Mycetophyllia and Diploria spp., may have been more common recruits on the east forereef than elsewhere. Small sample sizes preclude definitive statements on the latter point

Table 4 gives 15-mo net recruitment rates for the massive substrata found again in the field in 1978. Since no estimates of area were available, total numbers of corals are included for reference. Again the number of new colonies was lower in the sand channel, though original numbers were similar. Agariciids predominated, but less strikingly than in the restricted size class considered on the experimental substrata $(60$ to $67 \%$ of the total).
Growth

The number of surviving corals on which growth could be measured was not large, and the variance of the estimates is consequently great. On experimental substrata, mean growth was about $0.5 \mathrm{~cm}$ in 9 to $10 \mathrm{mo}$ for all species, though the range of variation was larger for poritids $(0.2$ to $1.3 \mathrm{~cm}$, as compared with 0.3 to $0.9 \mathrm{~cm}$ for agariciids). Small Porites astreoides Lesueur seemed to grow uncommonly fast, though the sample was too small for statistical testing. The largest colony $(0.8 \mathrm{~cm})$ at the first census, however, did not change size before the second.

In the field, the sole colony of Porites astreoides which persisted for $15 \mathrm{mo}$ did not grow either. Five other colonies 1 to $4 \mathrm{~cm}$ in diameter, which I have observed on the backreef ( $-1 \mathrm{~m}$ ) and on deep settlement panels (transite boxes at $-40 \mathrm{~m}$; see Buss and Jackson (1981) for photograph), have also shown no positive growth in periods ranging from 4 mo to $1 \mathrm{y}$.

Table 4. Field recruitment on natural substrata in 2 areas. Numbers of corals $\leq 5 \mathrm{~cm}$ across which were new at the second observation of fixed massive substrata, after $15 \mathrm{mo}$. Areas not measureable; total numbers at each observation given for reference

\begin{tabular}{|c|c|c|c|c|c|c|c|c|}
\hline \multirow[t]{3}{*}{ Species } & \multicolumn{4}{|c|}{ Upper Buoy Reef } & \multicolumn{4}{|c|}{ Sand channel } \\
\hline & \multicolumn{2}{|c|}{ Total numbers } & \multirow{2}{*}{$\begin{array}{l}\text { New } \\
1978\end{array}$} & \multirow{2}{*}{$\begin{array}{c}\% \text { New } \\
1978\end{array}$} & \multicolumn{2}{|c|}{ Total numbers } & \multirow{2}{*}{$\begin{array}{l}\text { New } \\
1978\end{array}$} & \multirow{2}{*}{$\begin{array}{c}\% \text { New } \\
1978\end{array}$} \\
\hline & $(1977)$ & 1978 & & & $(1977)$ & 1978 & & \\
\hline Stephanocoenia michelini & & & & & (2) & 2 & 2 & 100 \\
\hline Agaricia agaricites & $(28)$ & 34 & 21 & 62 & (35) & 20 & 9 & 45 \\
\hline Leptoseris cucullata & (9) & 8 & 5 & 63 & (5) & 8 & 5 & 63 \\
\hline Unidentified agariciids & (11) & 4 & 2 & 50 & (3) & 3 & 3 & 100 \\
\hline Porites astreoides & (2) & 3 & 2 & 67 & & & & \\
\hline Porites furcata & (5) & 9 & $6^{*}$ & 67 & $(0)$ & 1 & 1 & 100 \\
\hline Others & (4) & 4 & 1 & 25 & (4) & 4 & 1 & 25 \\
\hline Total & (59) & 62 & 37 & 61 & (49) & 38 & 21 & 55 \\
\hline
\end{tabular}


Table 5. Mortality of corals on experimental substrata. Minimum estimate (assuming some colonies are survivors which might be new), time 9 to 10 mo

\begin{tabular}{|c|c|c|c|c|c|c|}
\hline \multirow[t]{2}{*}{ Species } & \multicolumn{3}{|c|}{ Upper Buoy Reef } & \multicolumn{3}{|c|}{ Sand channel } \\
\hline & $\begin{array}{l}\text { Number at } \\
1 \text { st census }\end{array}$ & $\begin{array}{c}\text { Number gone } \\
\text { at } 2 \text { nd }\end{array}$ & Mortality & $\begin{array}{l}\text { Number at } \\
1 \text { st census }\end{array}$ & $\begin{array}{c}\text { Number gone } \\
\text { at } 2 \text { nd }\end{array}$ & Mortality \\
\hline Agaricia agaricites & 1 & 0 & 0 & & & \\
\hline Leptoseris cucullata & 1 & 1 & 1.00 & & & \\
\hline Unidentified agariciids & 282 & 271 & .96 & 81 & 80 & .99 \\
\hline Porites astreoides & & & & 13 & 6 & .46 \\
\hline Porites sp. & & & & 1 & 1 & 1.00 \\
\hline Montastrea annularis & & & & 1 & 1 & 1.00 \\
\hline Milleporasp. & 1 & 1 & 1.00 & & & \\
\hline Others (unidentified) & 13 & 11 & .85 & 8 & 7 & 88 \\
\hline Total & 298 & 284 & .95 & 104 & 95 & .91 \\
\hline
\end{tabular}

The sample size is small, even combining data from such disparate sources, but the pattern is striking in contrast to the rapid growth of smaller colonies.

The single young Acropora cervicornis observed on the marked substrata in the field increased from 2 to $5 \mathrm{~cm}$ in $15 \mathrm{mo}$ and acquired a $2 \mathrm{~cm}$ side branch. This growth was appreciably greater than that of the other species, though much less in absolute terms than that observed in larger colonies of $A$. cervicornis in this region (Rylaarsdam, 1980; Tunnicliffe, 1980).

\section{Mortality}

Total mortality of corals on experimental substrata exceeded $90 \%$ in both areas (Table 5). Mortality was greater for smaller corals, but the overall size distribution was too limited for this effect to be separated from species and position effects (Rylaarsdam, 1980).

Mortality on natural substrata was lower (Table 6) despite the longer time interval involved. Annual rates inferred from the 2 data sets are $97 \%$ and $54 \%$, evidence against the constant survivorship assumed in making the inferences. A $\chi^{2}$ test on the relationship between size and mortality on natural substrata is significant with $p<.025$, implying that larger corals have higher survivorship.

\section{Differential effects of injuries}

Several known causes of mortality were examined to see whether they were likely to produce differential mortality of the type observed among small corals or of the type which would have to occur among larger colonies to produce the abundance patterns of corals on the reefs.

\section{Damage by grazing Diadema}

Incidental damage to small corals by echinoids grazing primarily on algae was first suggested as a source of early mortality by Sammarco et al. (1974). I did laboratory experiments to estimate its quantitative importance. I collected branch rubble (primarily $A$. cervicornis but also some $P$. furcata) haphazardly at a

Table 6. Mortality of corals on natural substrata. Time 15 mo

\begin{tabular}{|c|c|c|c|c|c|c|}
\hline \multirow[t]{2}{*}{ Species } & \multicolumn{3}{|c|}{ Upper Buoy Reef } & \multicolumn{3}{|c|}{ Sand channel } \\
\hline & $\begin{array}{l}\text { Number at } \\
1 \text { st census }\end{array}$ & $\begin{array}{c}\text { Number gone } \\
\text { at } 2 \text { nd }\end{array}$ & Mortality & $\begin{array}{l}\text { Number at } \\
1 \text { st census }\end{array}$ & $\begin{array}{c}\text { Number gone } \\
\text { at } 2 \text { nd }\end{array}$ & Mortality \\
\hline Stephanocoenia michelini & & & & 2 & 2 & 1.00 \\
\hline Agaricia agaricites & 28 & 15 & .54 & 35 & 24 & .69 \\
\hline Leptoseris cucullata & 9 & 6 & .67 & 5 & 2 & .40 \\
\hline Unidentified agariciids & 11 & 9 & .82 & 4 & 3 & .75 \\
\hline Porites astreoides & 2 & 1 & .50 & & & \\
\hline Porites furcata & 5 & 2 & .40 & & & \\
\hline Millepora spp. & 2 & 2 & 1.00 & & & \\
\hline Others & 2 & 0 & 0 & 3 & 1 & .33 \\
\hline Total & 59 & 35 & .59 & 49 & 32 & .65 \\
\hline
\end{tabular}


depth of - 11 m on Upper Buoy Reef. In the laboratory, I examined each piece in seawater, under a microscope, recording species, size, condition, and position of each coral. Then I placed the rubble on the bottom of a large glass aquarium $(30 \times 80 \times 60 \mathrm{~cm})$ and added 5 Diadema antillarum also from Upper Buoy Reef. The density resembled that of Diadema on the forereef, but the ratio of urchins to available food may have been different, depending among other things on the growth rate of algae on the sides of the aquarium. This arrangement was nevertheless a fair imitation of natural conditions, judging by the generally untroubled behaviour of the Diadema. After $5 \mathrm{~d}$, I re-examined the rubble to record changes in the corals' condition, and see what fraction of those could be attributed to the activities of the sea urchins (by the presence of scrape marks on the coral or on the substratum where the coral had been). Since the marks made by the teeth of Diadema are unmistakable, and the examination of rubble was extremely time-consuming, no controls were used.

I repeated the same experiment 6 times with variable amounts of rubble, twice each in August and December of 1978 and January 1979. The total length of branches per trial ranged from 85 to $600 \mathrm{~cm}$. On 2 occasions, circumstances prevented complete examination of the rubble on the day of its collection, so that the sea urchins were held overnight before being added to the aquarium. This treatment affected their behavior, resulting in damage to coralline algae and the encrusting foraminiferan Gypsina as well as a marked increase in the number of corals bearing scrape marks.

Results of grazing experiments are given in Table 7 , which sums the data from all 6 trials. In 5 d, 92 of 394 corals showed some change in condition; 70 of these changes could be attributed to Diadema (outcomes 7 and 8 ). The damage done by Diadema was strongly size-dependent. Even excluding data from the trials in which the urchins were held overnight and more corals were injured, a $\chi^{2}$ on size and outcome is significant with $\mathrm{p}<.05$. The greatest contribution to that result comes from the number of corals in the smallest size class which were knocked off the substratum (14 out of 98 , in 4 trials), a much smaller component from the number in the second size class which were scraped but remained attached. The only suggestion of a species effect comes from the category 'unidentified agariciids' and is in fact another representation of the size effect.

\section{Overgrowth}

Although no systematic observations of overgrowth were made, the outcomes listed in Table 7 show that even in a short period of time, small corals can suffer extensive overgrowth by Gypsina and coralline algae (outcomes 4 and 6). The dead corals adjacent to

Table 7 . Changes in condition of small coral colonies after $5 \mathrm{~d}$ in aquariun with Diadema. Tabulated by (A) species and (B) size class. Score of $1 / 2$ indicates that a coral fell into 2 categories. Outcomes: 1 -dead, no apparent cause; 2 - partly dead, no apparent cause; 3 - dead, beside Gypsina; 4 - partly overgrown by Gypsina; 5 -dead, beside crustose algae; 6 - partly overgrown by crustose algae; 7 - partly scraped by Diadema; 8 - gone, substratum scraped by Diadema; 9 - roughly as before

\begin{tabular}{|c|c|c|c|c|c|c|c|c|c|c|c|}
\hline & & 1 & 2 & 3 & 4 & 5 & 6 & 7 & 8 & 9 & Total \\
\hline \multicolumn{12}{|c|}{ (A) Species } \\
\hline & Madracis decactis & & & & & & & & & 1 & 1 \\
\hline & Agaricia agaricites & 3 & 1 & 3 & $1-2 / 2$ & & 1 & $10-2 / 2$ & 2 & 131 & 154 \\
\hline & Leptoseris cucullata & & & & & & & & 1 & 14 & 15 \\
\hline & Unidentified agariciids & 3 & 1 & 2 & 1 & & & 9 & 34 & 111 & 161 \\
\hline & Porites astreoides & & & 1 & & & & 1 & 1 & 9 & 12 \\
\hline & Porites furcata & & & & 1 & & & & & 13 & 14 \\
\hline & Porites spp. & & & & & & & & 1 & 3 & 4 \\
\hline & Diploria labyrinthiformis & & 1 & & & & & & & 1 & 2 \\
\hline & Diploria sp. & & & & & & & 1 & & & 1 \\
\hline & Millepora spp. & & & & & & & & 1 & 3 & 4 \\
\hline & Others (unidentified) & & & 1 & 1 & 1 & & 2 & 5 & 16 & 26 \\
\hline \multirow[t]{8}{*}{ (B) } & Size Class & & & & & & & & & & \\
\hline & $<.5 \mathrm{~cm}$ & 3 & & 6 & 2 & 1 & & 7 & 38 & 119 & 176 \\
\hline & $.5 \mathrm{~cm}$ & 1 & 1 & 1 & $1-1 / 2$ & & 1 & $12-1 / 2$ & 6 & 64 & 88 \\
\hline & $1 \mathrm{~cm}$ & 1 & 2 & & $1-1 / 2$ & & & $3-1 / 2$ & 1 & 80 & 89 \\
\hline & $2 \mathrm{~cm}$ & 1 & & & & & & 1 & & 32 & 34 \\
\hline & $3 \mathrm{~cm}$ & & & & & & & & & 5 & 5 \\
\hline & $4 \mathrm{~cm}$ & & & & & & & & & 2 & 2 \\
\hline & Total & 6 & 3 & 7 & $4-2 / 2$ & 1 & 1 & $23-2 / 2$ & 45 & 302 & 394 \\
\hline
\end{tabular}


encrusting organisms (outcomes 3 and 5) either were killed indirectly or suffered some unidentified treatment effect (cf. outcome 1).

\section{Predation by Hermodice carunculata and Coralliophila abbreviata}

Prey preference experiments were conducted in the laboratory using Acropora cervicornis, Agaricia agaricites, and Montastrea annularis and the predators Hermodice carunculata and Coralliophila abbreviata, which can feed on corals of any size and many species (Marsden, 1962; Ott and Lewis, 1972; Glynn, 1973; Rylaarsdam, 1980). One healthy colony of each coral species (branches of Acropora 4 to $25 \mathrm{~cm}$, diameters of the other species 3 to $10 \mathrm{~cm}$ ) was placed in a tub with an independent water supply and either a single polychaete or a large number $(\sim 15)$ of gastropods. (The latter procedure was undertaken because of space limitations in the laboratory. It did not appear to affect the results, as the snails ate infrequently and without obvious reference to each other's activities.) The worms were collected from the backreef, where they were more accessible, the snails from Upper Buoy Reef at $-10 \mathrm{~m}$. (Originally I wanted to do separate trials for small snails $[<1 \mathrm{~cm}]$, as they occur on different substrata in the field; but at least in the laboratory they consumed no coral tissue. This need not mean that snails have no effect on corals, but it implies that they do not produce differential mortality, which was the problem under consideration in these experiments). The experiments were monitored at least once daily; when a coral was preyed upon, it and the predator were removed and replaced with fresh individuals. Intact colonies were not replaced, to minimize collecting.

All 30 worms which fed in the laboratory chose Acropora cervicornis rather than Agaricia agaricites or Montastrea annularis, despite the fact that they were from the backreef, where $A$. cervicornis is rare and the other species common. Of 32 snails which fed in the laboratory, 22 ate $A$. cervicornis, $10 \mathrm{M}$. annularis; $A$. agaricites was ignored. A $\chi^{2}$ test was significant with $\mathrm{p}<.001$.

\section{DISCUSSION}

Coral abundance patterns varied greatly within the cervicornis zone on the north coast of Jamaica (Table 1). Comparable communities exist on reefs elsewhere in the Caribbean. The pattern was due chiefly to differences in the absolute abundance of Acropora cervicornis among the 3 areas sampled, and to some extent to higher abundance of Montastrea annularis on the east forereef. Agaricia agaricites had similar absolute abundances in all areas; variations in its relative abundance reflected the differences in cover of the other species.

Processes acting at any stage in the corals' lives could affect the abundance patterns, but observations on the abundance and recruitment of small corals in the study areas showed that differential recruitment was relatively unimportant (assuming, of course, that the small-coral patterns were typical). Species composition of smaller size classes differed sharply from the relative abundances based on cover in all 3 areas, and exhibited greater similarity among areas (Fig. 2, Tables 1 to 4). Some differential recruitment did in fact occur. The number of corals on experimental substrata was highest on Upper Buoy Reef, lowest in the sand channel, suggesting that larvae were either avoiding the predominantly sandy area or settling only a short distance from parent colonies. Some support for the latter interpretation comes from the fact that at the first census at Upper Buoy Reef, where nearly all recruits were agariciids, over $40 \%$ of the corals were found in 1 of the 5 blocks of the experimental design (Rylaarsdam, 1980). No comparable densities were found elsewhere or at the second census, and there was no apparent correlation with the abundance of other sessile organisms or the presence of damselfish (cf. Kaufman, 1979), which could have suggested differential mortality. Such occurrences, however, could not account for the large-scale differences in cover.

The most striking feature of the small-coral abundance and recruitment data was the extreme rarity of acroporid and faviid corals (including Montastrea annularis). This was in marked contrast to their high cover. Bak and Engel's (1979) data on the relative abundances of small corals $(<4 \mathrm{~cm}$ across) in Curaçao are similar to those presented in Table 2 , and J. L. Wulff (pers. comm.) has analogous data from the Caribbean coast of Panama. Apparently the similarity of small-coral faunas in mid-depth forereef areas reflects fundamental characteristics of the principal species rather than local population phenomena on north Jamaican reefs.

Recruitment rates of different species on the experimental substrata (Table 3) varied more among areas than recruitment (Table 4 ) or relative abundance (Table 2) data for small corals on natural substrata. They may reflect temporal patchiness in settlement. If they are typical, however, they imply that subsequent growth and mortality differ strongly among areas, the size even of young colonies being poorly correlated with age. The observations of interrupted growth in Porites make the latter interpretation plausible.

Agariciid recruitment exceeded that of all other species at 2 censuses (Table 3). It may also occur more 
regularly (Van Moorsel, 1981), though the information on seasonal or sporadic recruitent of other corals is scrappy (but see Goreau et al., 1981). Regular observations over a long time are needed to resolve this point. It is especially interesting in view of the fact that much early mortality appears to be density-independent (Diadema grazing: this study; Sammarco, 1980; coralline algae and Gypsina: this study; and Bak and Engel, 1979; sand scour: Bak and Engel, 1979). If this mortality is uniformly distributed over time, recruits which appear continually in small numbers should benefit. On the other hand, seasonal recruitment is favored by seasonally limited mortality, e.g. if Diadema is much less active in stormy weather.

The abundance patterns produced by recruitment are altered by differential mortality. In the first few years of life, this tends to affect whole corals, much as though they were solitary organisms. Thus in $15 \mathrm{mo}$, field mortality of whole colonies $<5 \mathrm{~cm}$ in diameter averaged $62 \%$; (this figure corresponds closely to Bak and Engel's [1979] $32 \%$ in 6 mo, as both can be derived from a monthly mortality rate of $6.2 \%$ ).

The earliest differential mortality appears to be primarily a function of size. This was certainly true of the damage done by grazing Diadema in the laboratory (cf. Sammarco et al., 1974; Sammarco, 1976, 1980). Only 67 to $86 \%$ of the corals $<3 \mathrm{~mm}$ in diameter survived 5 d with Diadema, compared with $>95 \%$ of larger colonies. Extrapolation, with a conservative margin, suggests that a coral which remained $<3 \mathrm{~mm}$ in diameter for 2 to 3 mo would have about $80 \%$ chance of dying by the end of that time; the mortality observed in 9 to 10 mo on experimental substrata could easily have been produced by this cause. An escape in size probably also exists from overgrowth by Gypsina and coralline algae (this study; Bak and Engel, 1979).

Size may affect the susceptibility of corals to sand scour (Bak and Engel, 1979). At the sites in this study, scour affected few substrata, but the sediment trapped by mats of filamentous algae (cf. Potts, 1977) could have similar effects. Algae themselves have diverse effects: single filaments can be completely surrounded by small colonies of several coral species, but bladelike or partially encrusting algae such as Dictyota and Lobophora do more harm (Glynn, 1973; own obs.). Judging by the 5-d laboratory experiments, algae probably kill fewer corals than disturbance by Diadema, but their effects could be selective.

The advantages of settling at a relatively large size, as some rare recruits may do (own obs., < 25 corals: more data needed), or of growing very rapidly soon after settlement, as Porites spp. seem to do, are obvious. Such traits could lead to early differential survivorship among species; the data of this study are not enough to substantiate such patterns, but the superior survivorship of poritids on the experimental substrata is suggestive. Species differences of this type at this stage could have initiated the presumed transition to the observed general abundance patterns.

As colonies grow larger and partial mortality becomes more common, routine causes of tissue death seem to have less direct bearing on changes in relative abundance. For example, predation by Hermodice and Coralliophila is unlikely to produce the large-scale abundance patterns from the small-coral patterns. The results of limited prey preference experiments with these major predators suggest that their consumption of coral tissue would tend to enhance the small-coral pattern rather than change it. Some field observations agree with these results. Colonies of Acropora cervicornis often have freshly killed areas with marks characteristic of these predators (as well as damselfish bites and Diadema scrape marks, cf. Bak and van Eys, 1975; Kaufman, 1979).

The relatively high frequency of injuries to Montastrea annularis in the laboratory, as compared with Agaricia agaricites, conflicts with both my qualitative field observations and Bak and Luckhurst's (1980) mortality data from Curaçao, which indicate that $A$. agaricites suffers more visible injuries per sampling interval than $M$. annularis. The solution to the conflict may lie in the superior regenerative ability of $M$. annularis (Bak et al., 1977), which results in only very recent injuries being apparent. (A colony I observed in the laboratory took $2 \mathrm{wk}$ to repair a $1 \mathrm{~cm}$ natural lesion completely.) $M$. annularis tends to maintain its form, rather than adding new skeleton peripherally and abandoning old (Bak and Luckhurst, 1980; Rylaarsdam, 1980), but the turnover of soft tissue may be considerable, and the effect on the dynamics of other populations correspondingly large. Frequent (weekly or semi-weekly) field observations of marked colonies are needed to clarify the significance of laboratory results and establish the short-term dynamics of this species in more detail.

If routine processes alone cannot account for gross differences among areas, more attention should be given to long-term processes such as over growth and rare events such as toppling or breakage of colonies. Toppling of massive corals occurs commonly in severe winter storms, as the lost natural substrata showed, and, less often, in hurricanes. Montastrea annularis seems less susceptible to moderate disturbance than Agaricia agaricites (Bak and Luckhurst, 1980; own obs.); its high abundance on the exposed east forereef might have resulted from rarer toppling compensating for its low recruitment (this study; Bak and Engel, 1979) and slow growth (Buddemeier and Kinzie, 1976; Hudson, 1981). This hypothesis can only be tested by long-term observations of marked colonies in diverse 
habitats. Severe damage in hurricanes is evidently less discriminate (Porter et al., 1981; Woodley et al., 1981).

Overtopping of massive corals by Acropora spp. (Shinn, 1976; Porter et al., 1981) can lead after a few years to death of entire colonies. In the cervicornis zone, this occurs only when branches grow high and densely enough to form a mesh above massive colonies. The extent to which massive corals are limited must therefore depend on factors limiting $A$. cervicornis.

Acropora cervicornis is a very rare recruit: no new colonies occurred on either the experimental or the marked natural substrata, and the total number of small colonies found in counts in the cervicornis zone corresponded to a density of $<.5 \mathrm{~m}^{-2}$. It is evident, as has often been assumed, that high abundance of this species is due almost entirely to rapid growth of large colonies (sometimes $>20 \mathrm{~cm} \mathrm{yr}^{-1}$; Lewis et al., 1968; Glynn, 1973; Buddemeier and Kinzie, 1976; Gladfelter et al., 1980; Rylaarsdam, 1980; Tunnicliffe, 1980), and to dispersal by fragmentation (Gilmore and Hall, 1976; Shinn, 1976; Tunnicliffe, 1981; Highsmith, 1982). After ordinary storms, fragments can often be stabilized and saved from further damage if they have landed on material they are able to encrust; variable abundance of such material among areas may affect the development of coral abundance patterns over many years (Rylaarsdam, 1980). This hypothesis, again, should be tested by long-term observations, with particular attention to the periods following storms. After a severe storm, such as a hurricane, differential fragmentation among areas outweighs other influences on survivorship and subsequent propagation (Knowlton et al., 1981).

Over a long time, routine processes, slow developments, and catastrophes can all affect the development of differences among reef areas. Complex feedback may be important; the effects of one hurricane might depend on the effects of the one before and the time elapsed since. A great variety of developments is possible: it is important to understand that observations of a few reefs over a few years are indicative, not representative, of the interactions which can occur in a reef community of a given general type. Certain characteristics of the species can be considered constant, but their effects may depend on the context in which they occur. The widespread coexistence and variable abundance of common corals apparently owe much to the spatial and temporal patchiness of a Caribbean reef.

Acknowledgements. This paper is based on part of a dissertation submitted to The Johns Hopkins University in partial fulfillment of the requirements for a $\mathrm{Ph}$. D. It benefitted at various stages from comments by J. B. C. Jackson, S. A. Woodin, C. M. Wahle, N. Knowlton, J. C. Lang, K. W. Kauf- mann, F. W. Davis, and T. P. Hughes. The people who dived with me and provided other technical assistance are too numerous to list, but I thank them all, particularly the staff of the Discovery Bay Marine Laboratory. The work was supported in part by a dissertation improvement grant from the National Science Foundation and a Grant-in-Aid of Research from the Society of Sigma Xi. This is Contribution No. 295 of the Discovery Bay Marine Laboratory.

\section{LITERATURE CITED}

Bak, R. P. M., Brouns, J. J. W. M., Heys, F. M. L. (1977). Regeneration and aspects of spatial competition in the scleractinian corals Agaricia agaricites and Montastrea annularis. Proc. 3rd Int. Coral Reef Symp. 1: 143-148

Bak, R. P. M., Engel, M. S. (1979). Distribution, abundance, and survival of juvenile hermatypic corals (Scleractinia) and the importance of life history strategies in the parent coral community. Mar. Biol. 54: 341-352

Bak, R. P. M., Luckhurst, B. E. (1980). Constancy and change in coral reef habitats along depth gradients at Curaçao. Oecologia (Berl.) 47: 145-155

Bak, R. P. M., van Eys, G. (1975). Predation of the sea urchin Diadema antillarum Philippi on living coral. Oecologia (Berl.) 20: 111-115

Barnes, D. J. (1973). Growth in colonial scleractinians. Bull. mar. Sci. 23: 280-298

Buddemeier, R. W., Kinzie, R. A. III (1976). Coral growth. Oceanogr. mar. biol. A. Rev. 14; 185-225

Buss, L. W., Jackson, J. B. C. (1981). Planktonic food availability and suspension feeder abundance: evidence of in situ depletion. J. exp. mar. Biol. Ecol. 49: 151-161

Gilmore, M. D., Hall, B. R. (1976). Life history, growth habits, and constructional roles of Actopora cervicornis in the patch reef environment. J. sedim. Petrol. 46: 519-522

Gladfelter, E. H., Monahan, R. K., Gladfelter, W. B. (1978). Growth rates of five reef-building corals in the northeastern Caribbean. Bull. mar. Sci, 28: 728-734

Glynn, P. W. (1973). Aspects of the ecology of coral reefs in the Western Atlantic region. In: Jones, O. A., Endean, R. (eds.) Biology and geology of coral reefs, Vol. 2. Academic Press, London, p. 271-324

Goreau, T F. (1959). The ecology of Jamaican coral reefs. I. Species composition and zonation. Ecology 40:67-90

Goreau, T F., Goreau, N. I. (1973). The ecology of Jamaican coral reefs. II. Geomorphology, zonation, and sedimentary phases. Bull. mar. Sci. 23: 399-464

Goreau, N. I., Goreau, T. J., Hayes, R. M. (1981). Settling, survivorship, and spatial aggregation in planulae and juveniles of the coral Porites porites (Pallas). Bull. mar. Sci. 31: 424-435

Harper, J. L. (1977). The population biology of plants. Academic Press, London, New York

Highsmith, R. C. (1982). Reproduction by fragmentation in corals. Mar. Ecol. Prog. Ser. 7: 207-226

Hudson, J. H. (1981). Growth rates in Montastrea annularis: a record of environmental change in Key Largo Coral Reef Marine Sanctuary, Florida. Bull. mar. Sci. 31: 444-459

Hughes, T. P., Jackson, J. B. C. (1980). Do corals lie about their ages? Some demographic consequences of partial mortality. Science, N. Y. 209: 713-715

Kaufman, L. S. (1979). Damselfish disturbance on Caribbean coral reefs. Ph. D. dissertation, The Johns Hopkins University, Baltimore

Kinzie, R. A. III (1973). The zonation of West Indian gorgonians. Bull. mar. Sci. 23: 93-155 
Knowlton, N., Lang, J. C, Rooney, M. C., Clifford, P. (1981). When hurricanes kill corals: evidence for delayed mortality in Jamaican staghorns. Nature, Lond. 294: 251-252

Lang, J. C. (1973). Interspecific aggression by scleractinian corals. 2. Why the race is not only to the swift. Bull. mar Sci. 23: 260-279

Lewis, J. B. (1974). Settlement and growth factors influencing the contagious distribution of some Atlantic reef corals. Proc. 2nd Int. Coral Reef Symp. 2: 201-206

Lewis, J. B., Axelson, F., Goodbody, I., Page, C., Chislett, G. (1968). Comparative growth rates of some reef corals in the Caribbean. Ms. report, Mar. Sci. Center, McGill University, Montreal 10: 1-26

Marsden, J. R. (1962). A coral-eating polychaete. Nature, Lond. 193: 598

Ohlhorst, S. L. (1980). Jamaican coral reefs: important biological and physical parameters. Ph. D. dissertation, Yale University, New Haven

Ott, B., Lewis, J. B. (1972). The importance of the gastropod Coralliophila abbreviata (Lamarck) and the polychaete Hermodice carunculata (Pallas) as coral reef predators. Can. J. Zool. 50: 1651-1656

Pielou, E. C. (1977). Mathematical ecology. John Wiley \& Sons, New York, London, Toronto

Porter, J. W. (1972). Patterns of species diversity in Caribbean reef corals. Ecology 53: 745-748

Porter, J. W., Woodley, J. D., Smith, G. J., Neigel, J. E., Battey, J. F., Dallmeyer, D. G. (1981). Competition and catastrophe: population trends among Jamaican reef corals. Nature, Lond. 294: 249-250

Potts, D. C. (1977). Suppression of coral populations by filamentous algae within damselfish territories. J. exp. mar. Biol. Ecol. 28: 207-216

Rylaarsdam, K. W. (1980). Life histories and abundance pat- terns of some common Caribbean reef corals. Ph. D. dissertation, The Johns Hopkins University, Baltimore

Sammarco, P. W. (1976). Grazing by Diadema antillanum Philippi (Echinodermata, Echinoidea): density dependent effects of coral and algal community structure. Proc. Ass. Isl. Mar. Labs. Carib. 11: 19

Sammarco, P. W. (1980). Diadema and its relation to coral spat mortality: grazing, competition, and biological disturbance. J. exp. mar. Biol. Ecol. 45: 245-272

Sammarco, P. W., Levinton, J. S., Ogden, J. C. (1974). Grazing and control of coral reef community structure by Diadema antillarum Phillips (Echinodermata, Echinoidea): a preliminary study. J. mar. Res. 32: 47-53

Shinn, E. A. (1976). Coral reef recovery in Florida and the Persian Gulf. Environ. Geol. 1: 241-254

Tunnicliffe, V. J. (1980). Biological and physical processes affecting the survival of a stony coral, Acropora cervicornis. Ph. D. dissertation, Yale University, New Haven

Tunnicliffe, V. J. (1981). Breakage and propagation of the stony coral Acropora cervicornis. Proc. natn. Acad. Sci U.S.A. 78: $2427-2431$

Van Moorsel, G. W. N. M. (1981). Different reproductive strategies in two closely related stony corals (Agaricia Scleractinia). (Abstract) 4th Int. Coral Reef Symp.

White, J. (1979). The plant as a metapopulation. Ann. Rev Ecol. Syst. 10: 109-145

Woodley, J. D., Chornesky, E. A., Cliffort, P. A., Jackson, J. B C., Kaufman, L. S., Knowlton, N., Lang, J. C., Pearson, M. P., Porter, J. W., Rooney, M. C., Rylaarsdam, K. W., Tunnicliffe, V. J., Wahle, C. M., Wulff, J. L., Curtis, A. S. G. Dallmeyer, M. D., Jupp, B. P., Koehl, M. A. R., Neigel, J., Sides, E. M. (1981). Hurricane Allen's impact on Jamaican coral reefs. Science, N. Y. 214:749-755 